på øvelser, instabilitet og hvordan man vurderer den enkelte pasient klinisk-funksjonelt.

Boken består av tre hovedkapitler med 13 underkapitler. Første del omhandler vitenskapelig forankring, epidemiologi og funksjonell anatomi/biomekanikk. Sistnevnte er meget grundig og i stor grad basert på forfatterens egen forskning. Kapitlet om myter og realiteter knyttet til begrepet stabilitet og om hva som hjelper av øvelser, er fortsatt høyst relevant. Del 2 gir en grundig innføring i dagens forskningsbaserte viten om skademekanismer og forebygging, med særlig vekt på sport og arbeid, f.eks. løfteteknikker og utholdenhetstrening. Del 3 omhandler rehabilitering, treningsopplegg og øvelser med solide begrunnelser. Det er tankevekkende at mange råd vi har gitt $\mathrm{i}$ årevis kanskje er mer til skade enn til gagn, for eksempel tradisjonelle «sit-ups». En god opplysning for bokanmelderen, som er et utpreget B-menneske, er at man skal være varsom med ryggøvelser like etter at man har stått opp om morgenen. $\mathrm{Og}$ fortsatt gjelder at vi stadig bør variere aktivitet, kroppsbelastning og stilling - både når vi sitter, driver sport og er på jobb. Særlig synes jeg mange av de ergonomiske rådene både er gode og kunnskapsbaserte.

Boken er, som forrige utgave, velskrevet, oversiktlig og lettlest, selv om stoff- og detaljmengden er betydelig, ikke minst om funksjonelle og biomekaniske aspekter. Referanselisten er omfattende, men i hvilken grad den bygger på systematiske søk og vurderinger, fremgår ikke.

Om den kliniske hverdagsunders $ø$ kelse og håndtering tror jeg ikke norske ryggklinikere vil finne så mye nytt og nyttig. Boken fremstår her noe fragmentarisk og omhandler blant annet ikke noe om kommunikasjon eller tverrfaglig samarbeid. Det siste er ikke minst viktig når det gjelder rehabilitering. I så måte finnes det etter mitt skjønn andre og bedre alternativer $(1,2)$.

For alle med spesiell interesse for biomekanikk, skademekanismer og trening/ øvelser kan jeg varmt anbefale også denne 2. utgaven.

\section{Even Lærum}

Formidlingsenheten for muskel-

og skjelettlidelser

Ullevål universitetssykehus

\section{Litteratur}

Lærum E, Brox Jl, Storheim K et al. Nasjonale kliniske retningslinjer for korsryggsmerter med og uten nerverotaffeksjon. Oslo: Formidlingsenheten for muskel- og skjelettlidelser (FORMI) og Sosialog helsedirektoratet, 2007.

2. Waddell G. The back pain revolution. New York NY: Churchill Livingston, 1999

\section{Vanskelige samtaler med barn}

Raundalen M, Schultz J-H

Kan vi snakke med barn om alt?

143 s, ill. Oslo: Pedagogisk forum, 2008.

Pris NOK 240

ISBN 978-82-7391-149-0

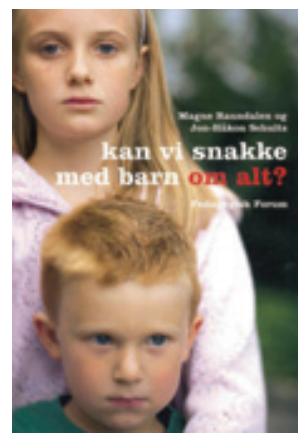

Denne boken om samtaler med barn om de vanskeligste hendelser i livet som krig, katastrofer, sorg og tap henvender seg til «alle barnevennlige og barnefaglige: førskolelærere, lærere, helsesøstre, barnevernet, foreldre, bestefor-

eldre, onkler, tanter og alle de andre som har tid til å snakke med barn». Den er et resultat av et samarbeid med Barne- og familiedepartementet om veiledning til foreldre og fagfolk, utgitt med støtte fra nettverket Skal-skal ikke.

Boken består av i alt ni kapitler, der allerede tittelen i første kapittel slår an grunntonen: Respekt for barnets forstand. Kapitlene kan leses hver for seg og i tilfeldig rekkefølge, og kapittelskillene markeres med bilder av tenksomme barn, noe som gir boken et tiltalende preg. Det er en liten, men ikke lettlest bok. Viktigst er likevel det gjennomgående budskapet: Barn tenker, barn oppfatter og barn trenger at voksne gir dem et verktøy til å forstå og få sammenheng i det de erfarer. Samtalen er et slikt verktøy, men den må legges på et nivå som er tilpasset barnets alderstrinn. Barn blir redde når de ikke forstår, og forfatterne avslutter med følgende kommentar: «Det er ikke skadelig for barn å snakke, og det er ikke galt av oss å lytte.»

Forfatterne er seg bevisst at de er kjente fagpersoner som brukes mye som rådgivere ved kriser og katastrofer, og de deler raust av sine erfaringer. Boken oppfyller sin intensjon med klare oppskrifter og veiledning, selv om det for denne leser blir i overkant mye «vi var der og vi gjorde slik».

I en hverdag der mediene eksponerer familietragedier og bringer ulykker og katastrofer inn i hvert hjem, er det viktig at både familie, venner og fagpersoner tør å snakke med barn om vanskelige temaer. Etterspørselen etter veiledning er stor. Likevel er det et spørsmål om ikke denne boken favner for vidt. Det legges så stor vekt på samtaler og opplegg på skoler og i barnehager at man lett kan få følelsen av at det er fagpersoner som tar seg av de viktige samtalene med barnet. Foreldreperspektivet blir utydelig, og det er neppe forfatternes hensikt. Hvordan man vinkler samtaler i barne- grupper og hvordan man møter barnets tydelige og utydelige spørsmål hjemme, er to ulike ting. Å møte barn i sorg og krise er så viktig at man med fordel kunne delt målgruppen $i$ to og laget en egen veileder for foreldre/foresatte/nær familie.

\section{Jannike Engelstad Snoek}

Senter for psykisk helse barn og unge

Ullevål universitetssykehus

\section{Unges egne historier om sorg}

Dyregrov A, Gjestvang B, Slagsvold M.

Ung sorg

14 unge om døden og livet videre. 256 s, ill.

Oslo: Aschehoug, 2008. Pris NOK 349

ISBN 978-82-03-23574-0

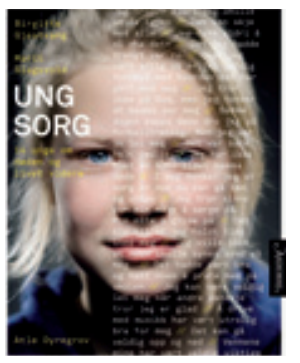

14 unge mennesker forteller om sin sorg over å ha mistet en som sto dem nær. Forfatterne har ønsket å formidle de unges erfaringer for å hjelpe andre i liknende situasjoner og for å rette oppmerksomheten mot hvordan sorg kan arte seg for barn og ungdommer. De står frem med personlige historier, bilde og navn - en form som krever personlig mot og varsomhet fra forfatterne. Historiene fremstår som svært troverdige, direkte $\mathrm{i}$ formen og befriende fri for klisjeer. De unges personlige fortellinger gir innblikk i de mange ulike uttrykk sorgen har: sinne, fortvilelse, utagerende atferd, tilbaketrekning, savn og overveldende tristhet. Slike reaksjoner kan prege de unges utvikling og sosiale tilpasning i lange perioder og få konsekvenser for skolegang, vennerelasjoner og psykisk helse, slik flere av de unge også forteller om. Noen av historiene illustrerer også hvordan praktiske problemer kan legge en ekstra bør og ansvar på unge mennesker i sorg.

Sorg er en normal reaksjon på tap av noen som står oss nær, og boken gir på en god måte en forståelse for sorg hos unge mennesker. Mange av historiene er imidlertid dramatiske, og mange av de unge har opplevd en svært vanskelig livssituasjon i etterkant av tapet. Bistand fra hjelpeapparatet har derfor vært nødvendig for mange av dem som står frem, noe som verken er nødvendig eller naturlig etter de fleste dødsfall.

Psykolog Atle Dyregrov avslutter med en oppsummering av hovedinntrykkene fra historiene som er fortalt, og knytter dem til egne erfaringer i møtet med barn, ungdom og voksne i sorg. Som viktige kjennetegn på sorgprosessen understreker han bl.a. mangfoldet i reaksjoner, at det ikke er noen 
oppskrift på hvordan man skal sørge og at sorg tar tid. Vanlige reaksjoner som skyldfølelse, redsel og sinne, og hvordan sorg og tap kan påvirke samspillet i familien, forhold til venner og skole blir beskrevet mer inngående. Underveis kommer Dyregrov med en rekke konkrete selvhjelpsråd til den som er i sorg, samt råd til mennesker som skal støtte den som har mistet en kjær person. Kapitlet avsluttes med noen viktige tegn på når man trenger profesjonell hjelp.

Dyregrov formidler kunnskap om sorg på en svært informativ og matnyttig måte, som vil komme mange lesere til gode. Selv om de faglige rådene er mange, understrekes betydningen av at hver og en må finne sin vei igjennom sorgen. Kapitlet er detaljert og relativt omfattende, men kunne etter vår mening med fordel vært strammet noe inn, både for å unngå gjentakelser og for å gjøre det enda mer lettlest og oversiktlig for leseren.

Boken anbefales både til profesjonelle og andre som søker kunnskap om barn og unge i sorg.

\section{Grete Dyb}

Pål Kristensen

Nasjonalt kunnskapssenter om vold og traumatisk stress

Universitetet i Oslo

\section{Gynekologi for allmennleger}

Gudim HB, Juvkam KH. Gynekologi

Kort og godt. 280 s, tab, ill. Oslo: Universitetsforlaget, 2008. Pris NOK 299 ISBN 978-82-15-00790-8

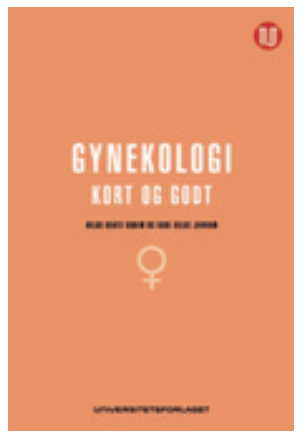

Gynekologi. Kort og godt bygger på forfatternes tidligere utgivelse Gynekologi i allmennpraksis (1).

Som den første er også denne tradisjonelt oppbygd og starter med den gynekologiske undersøkelsen som første kapittel, deretter følger 15 kapitler som favner de sentrale gynekologiske emner som ungdomsgynekologi, infertilitet, abort, hormonell dysfunksjon, blødningsforstyrrelser, benigne og maligne svulster osv. Det er fra forrige utgivelse tilkommet to temaer: undersøkelse av personer som har vært utsatt for seksuelle overgrep, og kjønnslemlestelse (omskjæring). Det er referanser og nettadresser etter hvert kapittel, oftest over 1-2 sider. En rekke spesialister, hvorav de fleste er gynekologer, er i forordet takket for sine bidrag. Primærmålgruppene er medisinstu- denter, turnuskandidater og allmennpraktikere.

De fleste kapitlene er utmerkede og bærer preg av at forfattere og bidragsytere har inngående kunnskap og erfaring på feltet. De gir oppdatert og ofte konsis informasjon. Gode eksempler på dette er kapitlene om genitale infeksjoner, prevensjon, klimakteriet og premaligne og maligne tilstander. Nivået er imidlertid noe ujevnt, og iblant er rådene som gis absolutt diskuterbare: f.eks. om myomer anføres uten reservasjon at myom i nedre segment er indikasjon for keisersnitt. Det er jo på ingen måte gitt, og man burde i stedet rådet til å henvise til fødeavdeling for vurdering. Et annet eksempel: ved palpasjon av myomer og behov for nærmere avklaring er det gjerne et bedre forslag å henvise til gynekolog enn å henvise til MR, slik boken foreslår. Hvorfor cytologisk prøvetaking ved synlig portiopatologi kan forsinke rett diagnose, er også vanskelig å forstå. Videre: om cervixcancer skrives at hysterektomi kan vurderes om det ikke er viktig å bevare fertilitet. Antakelig er setningen ment for helt tidlige stadier av sykdommen - i senere stadier blir vel fertilitet underordnet. Noen inkonsekvenser forekommer iblant også: om abort anføres at ukomplisert spontanabort før sjuende uke ikke behøver henvisning, et annet sted anføres at man ved spontanabort oftest behøver utskrapning. Det siste utsagnet står også i kontrast til dagens praksis.

Noen flytskjemaer kunne lettet fremstillingen, for eksempel under infertilitetsutredning, og man kunne her - som andre steder - gjerne ha antydet en grenseoppgang mellom allmennpraktiker og spesialist. Målgruppen vil nok ha nytte av en noe klarere angivelse av hva som forventes på allmennlegekontoret og hva som bør henvises. Språket kunne stedvis vært bedre. Tross noen svakheter er innhold og form bra nok til at boken trygt kan anbefales målgruppen.

\section{Knut Hordnes}

Kvinneklinikken

Haukeland universitetssykehus

\section{Litteratur}

1. Gudim HB, Juvkam KH. Gynekologi i allmennpraksis. Oslo: Tano Aschehoug, 1999.

\section{God akuttmedisinsk bibel}

Adams JG, red

Emergency medicine

2276 s, tab, ill. Philadelphia, PA: Saunders

Elsevier, 2008. Pris USD 189

ISBN 978-1-4160-2872-7

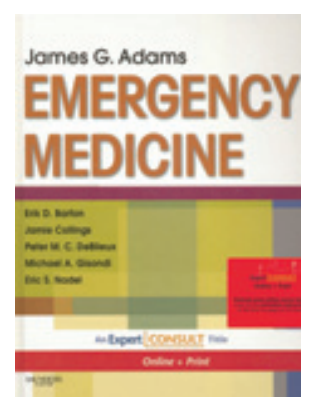

Akuttmedisin er et svært omfattende fagområde, og i eksempelvis USA og Storbritannia finnes akuttmedisin som egen medisinsk spesialitet. Pasienter med skader og akutte lidelser blir her oftest henvist til sykehusbaserte legevakter. Spesialister i akuttmedisin skal således kunne håndtere alle akutte tilstander, både det som i Norge håndteres i førstelinjetjenesten og det som gjøres i sykehus den første tiden etter innleggelse i akuttmottak.

Det er derfor ikke så rart at en bok som tar for seg dette fagområdet på en grundig og omfattende måte, blir på mer enn 2000 sider. Det er imponerende at redaktøren har klart å samle bidrag fra mer enn 250 forfattere. Riktignok er det bare amerikanske kolleger som har bidratt, men det er greit ikke bare å lese tekster fra velkjente artikkelforfattere. På den annen side gjenspeiler boken amerikanske behandlingstradisjoner. Men dette er ikke noe problem, fordi teksten stort sett er glimrende når det gjelder anamnese, undersøkelser og diagnostiske vurderinger.

Så å si alle akuttmedisinske problemstillinger dekkes: fra gjenoppliving, via akutte tilstander i alt fra hud, knokler og ledd, ørenese-hals, gynekologi og psykiatri, til forgiftninger. I tillegg er det utmerkede og interessante kapitler om ledelse, kvalitetsutvikling, pasientsikkerhet, konflikthåndtering og etiske problemstillinger innen fagområdet.

Boken er utrolig godt illustrert med tabeller, figurer og skarpe fotografier, hvorav mange er i farger. Der er også massevis av røntgen- og ultralydbilder med gode beskrivelser. Kapitlene har videre hensiktsmessige tekstbokser med for eksempel viktige momenter, algoritmer, differensialdiagnoser, feilkilder og praktiske lister med alt fra diagnostiske håndgrep til konkrete spørsmål til pasienten.

Referansene er omfattende, relevante og oppdaterte. Det er ikke så ofte man ser referanser som er ferskere enn ett år i et så omfattende bokverk, den omfattende redigerings- og trykkeprosessen tatt i betraktning. De aller fleste kapitlene er skrevet på et konsist og lettfattelig språk, og det er få trykkfeil. Stikkordlisten er omfattende og god. 